\title{
PERBEDAAN TINGKAT KECEMASAN IBU HAMIL PRIMIGRAVIDA DENGAN MULTIGRAVIDA DI ERA PANDEMI COVID-19 \\ DI WILAYAH KABUPATEN KENDAL
}

\author{
Rozikhan $^{1}$ Titik Sapartinah ${ }^{2}$ \\ 1,2,3 UPP Kampus Kendal, Poltekkes Kemenkes Semarang, Indonesia
}

\begin{abstract}
Anxiety that occurs in pregnant women is a serious problem because the mortality rate for pregnant women is $80 \%$ due to high anxiety. The emergence of anxiety due to influencing faktors, including internal faktors of pregnancy it self and external faktors due to the family environment and the environment outside the family. In developed countries the level of anxiety is around $7-20 \%$ and in developing countries more than $20 \%$. The level of anxiety that occurs in primigravida pregnant women is greater than that of multigravida pregnant women, but in the era of the Covid-19 pandemic it can increase anxiety in pregnant women, especially those who are approaching childbirth process. The Objective of this research is there a difference in the level of anxiety between primary and multi-pregnant women in the era of Covid-19 pandemic. The design of this research uses crosscectional study, where between exposure and outcame is seen at the same time. The sampling method used accidental sampling, obtained a total of 72 respondents, consisting of 21 respondents with primigravida status and 51 respondents with multigravida status. The research analysis used the compare mean of independent sample t-test. The primigravida-pregnant women is more anxiety (57.1\%) compared to multi-pregnant women (27.4\%). There is a significant difference in the value of anxiety between primary and multi pregnant women in the trimester III in the era Covid-19 pandemic, ( $p$ value $0.003<0.05$ )
\end{abstract}

Keywords : Anxiety; Pregnancy; Covid 19 


\section{PENDAHULUAN}

Kehamilan adalah periode yang dihitung dari hari pertama haid terakhir (HPHT) hingga mulainya persalinan sejati, ini yang menandai awal periode antepartum. Periode antepartum dibagi menjadi tiga trimester yang masingmasing terdiri dari 13 minggu atau tiga bulan menurut hitungan kalender. Pembagian waktu ini diambil dari ketentuan yang mempertimbangkan bahwa lama kehamilan diperkirakan kurang lebih 280 hari, 40 minggu, 10 bulan, atau 9 bulan sejak hari pertama haid terakhir (HPHT) (Varney 2006, 492). Meskipun kehamilan adalah suatu proses alami namun kehamilan dapat menimbulkan berbagai permasalahan baik permasalahan secara fisik maupun permasalahan psikologis. Permasalahan fisik dalam proses kehamilan, misal banyaknya usia ibu hamil yang terlalu muda atau usia yang sudah tua, terlihat dari hasil yang pernah dilakukan penelitian 2007 diperoleh ibu hamil dengan usia $<20$ sebanyak $8 \%$ dan ibu usia $>35$ th sebanyak $6,5 \%$, yang mempunyai riwayat hipertensi sebesar 21 \%.(Rozikhan, 2007).

Permasalahan yang terkait dengan psikologi adalah kecemasan yang timbul karena faktor kehamilan itu sendiri (internal) dan kecemasan yang timbul karena pengaruh lingkungan (eksternal). Menurut Mapierre (2009), terdapat berbagai faktor yang dapat mempengaruhi kecemasan selama kehamilan diantaranya usia ibu, tingkat pendidikan dan dukungan keluarga termasuk dukungan suami. Berdasarkan hasil penelitian Wanda et al (2014), graviditas dan pekerjaan berhubungan dengan kecemasan ibu hamil dalam menghadapi persalinan. Prevalensi kecemasan dan depresi pada negara maju sekitar $7-20 \%$ dan di negara berkembang sekitar lebih dari 20\% (Biaggi et al, 2016). Kecemasan pada kehamilan merupakan reaksi emosional yang terjadi pada ibu hamil terkait dengan kekhawatiran ibu dengan kesejahteraan diri dan janinnya, keberlangsungan kehamilan, persalinan, masa setelah persalinan dan ketika telah berperan menjadi ibu (Schetter \& Tanner,2012)

Kecemasan selama kehamilan dapat disebabkan oleh adanya perubahan fisik, ketakutan terhadap persalinan dan transisi peran menjadi orang tua (Varney et al., 2010). Berdasarkan hasil penelitian Astuti (2005) menunjukkan sebesar $46 \%$ ibu yang mengalami kecemasan ringan, 50\% kecemasan sedang dan $4 \%$ kecemasan berat dari 50 ibu hamil Di era pandemi covid -19 penyebaran wabah virus corona yang sangat cepat, melebihi kemampuan ilmuwan menciptakan vaksin dan obat yang efektif, memang mengkhawatirkan. Tak heran jika banyak orang mengalami kecemasan termasuk ibu hamil. Sebuah survei yang dilakukan Asosiasi Psikiatri Amerika (APA) terhadap lebih dari 1000 orang dewasa di Amerika serikat, 
ditemukan bahwa 48 persen responden merasa cemas mereka akan tertular virus corona. Presiden APA, Dr.Bruce Schwartz mengatakan, stres dan kecemasan yang disebabkan oleh pandemi bisa berdampak pada kesehatan fisik dan mental. Sekitar 40 persen mengkhawatirkan mereka akan mengalami sakit berat atau meninggal akibat Covid-19, dan 62 persen mencemaskan keluarga atau orang tercintanya tertular. Lebih dari sepertiga responen (36 persen) mengatakan pandemi Covid-19 berdampak serius pada kesehatan mental mereka, dan 59 persen menjawab efeknya cukup berat pada kehidupan sehari-hari. Disamping hal tersebut kecemasan terbesar para responden terkait pandemi ini adalah pengaruh pada keuangan, kekurangan makanan, obat, dan kebutuhan lainnya. Covid-19 sebagai pandemi global tentu saja memberi dampak yang sangat serius bagi Indonesia sehingga membuat banyak orang harus melakukan Physical distancing (menjaga jarak fisik) dari keramaian agar terhindar penyebaran Covid-19. Ribuan karyawan di-PHK (Putus Hubungan Kerja), berdampak pada buruh bahkan tukang sepatu sekalipun kesulitan mencari nafkah. ( Kompas.com.,2020)

\section{METODOLOGI PENELITIAN}

Subyek penelitian adalah ibu hamil trimester III yang diambil melalui accidental sampling dimana responden diambil dari ibu hamil trimester III yang melakukan pemeriksaan di pelayanan kesehatan serta ibu hamil trimester III yang ada di wilayah bidan desa puskesmas Kaliwungu dan Brangsong 2 terhitung mulai bulan Agustus 2020. Alat yang digunakan unutk pengambilan data adalah berupa kuesioner HARS ( Hemilton Rating Scale Of Anxiety).

\section{HASIL PENELITIAN DAN BAHASAN}

Proses pengambilan data dilakupan pada periode Agustus s/d Oktober 2020 di wilayah kerja Puskesmas Brangsong dan Puskesmas Kaliwungu Kabupaten Kendal. Tim peneliti mendapatkan jumlah responden sebanyak 74 yang terdiri dari ibu hamil primipara dan ibu hamil multipara untuk dilihat masing-masing tingkat kecemasannya.

Tabel.1 Distribusi frekuensi kategori kehamilan dengan kategori tingkat kecemasan di era Pandemi covid-19.

\begin{tabular}{lllll}
\hline Kehamilan & \multicolumn{3}{c}{ Kecemasan } & Total \\
\cline { 2 - 4 } & $\begin{array}{l}\text { Tidak } \\
\text { cemas }\end{array}$ & ringan & sedang \\
\hline Primi & $9(42,9 \%)$ & $7(33,3 \%)$ & $5(23,8 \%)$ & 21 \\
Multi & $37(72,6 \%)$ & $13(25,5 \%)$ & $1(1,9 \%)$ & 51 \\
& & & & \\
\hline Jumlah & $46(63,9 \%)$ & $20(27,8 \%)$ & $6(8,3 \%)$ & 72 \\
\hline
\end{tabular}

Tabel 2. Perbedaan tingkat Kecemasan Ibu Hamil Trimester III Primigravida dan Multigravida di era Pandemi Covid 19

\begin{tabular}{lcccc}
\hline Hamil & $F n$ & Mean & $\begin{array}{l}p- \\
\text { value }\end{array}$ & $95 \% \mathrm{Cl}$ \\
\hline Primigravida & 21 & 14,7 & 0,003 & $\begin{array}{l}1,53- \\
6,91\end{array}$ \\
Multi & 51 & 10,5 & & \\
\hline Jumlah & 72 & & & \\
\hline
\end{tabular}


Penelitian tentang tingkat kecemasan yang terjadi pada ibu hamil trimester III menggunakan kuesioner menurut Hamilton rating scale for anxiety (HARS) diperoleh hasil tabulasi silang bahwa ibu hamil multi lebih banyak tidak mengalami cemas $(72,6 \%)$ dibandingkan dengan ibu hamil primigravida (42,9\%). Akan tetapi ibu hamil yang mengalami kecemasan ringan lebih banyak dialami ibu hamil primigravida (33,3\%) disbanding dengan ibu hamil yang multi (25,5\%). Hasil penelitian ini tidak jauh beda dengan beberapa penelitian sebelumnya salah satunya yaitu hasil penelitian dari Debora V. V. Mandagi, Cicilia Pali, Jehosua S. V. Sinolungan tahun 2013 dengan tema Perbedaan tingkat kecemasan pada primigravida dan multigravida di RSIA kasih ibu Manado dengan menggunakan kuesioner yang sama yaitu Hamilton Anxiety Rating Scale (HARS). Hasil penelitian ditemukan 20 orang tidak mengalami cemas, $30 \%$ pada primigravida dan $36,7 \%$ pada multigravida. Sebanyak 9 orang mengalami cemas ringan, 16,7\% primigravida dan 13,3\% multigravida. Sebanyak 1 orang mengalami cemas sedang yaitu pada primigravida. Sedangkan hasil uji t-test diperoleh perbedaan yang signifikan antara tingkat kecemasan ibu hamil primigravida dan multi di usia kehamilan trimester III di era pandemic covid-19 dimana nilai rata-rata kecemasan ibu hamil primigravida sebesar 14,7 (mengalami cemas ringan), sedangkan nilai rata-rata kecemasan ibu hamil multigravida sebesar 10,5 (Tidak mengalami kecemasan). Hasil penelitian ini sejalan dengan hasil penelitian Dwi Ayu Metasari Fakultas kedokteran Universitas Muhammadiyah Surakarta tahun 2016 dengan tema perbedaan tingkat kecemasan antara primigravida dan multigravida trimester ketiga di Puskesmas Dawe Kabupaten Kudus, diketahui rata-rata tingkat kecemasan primigravida sebesar 24,40. Pada multigravida sebanyak 17,23 dan diperoleh nilai $p<0,001$ sehingga dapat disimpulkan terdapat perbedaan yang signifikan antara pasien primigravida dan multigravida trimester ketiga. Akan tetapi beberapa penelitian yang terdahulu berbeda dalam masalah waktu bila dibandingkan dengan waktu penelitian yang dilakukan oleh peneliti, misalnya penelitan yang telah dilakukan oleh Dwi Ayu Metasari maupun penelitian yang dilakukan oleh Debora V. V. Mandagi, Cicilia Pali, Jehosua S. V. Sinolungan adalah pada waktu yang normal tanpa ada peristiwa pandemic yang secara psikologis maupun social dapat membuat masyarakat menjadi cemas, tetapi ternyata hasilnya tidak jauh beda sehingga dengan hasil penelitian ini dapat diasumsikan bahwa kondisi pandemic covid-19 tidak banyak berpengaruh terhadap peningkatan kecemasan pada ibu hamil, dimungkinkan kecemasan yang dialami oleh ibu hamil trimester III cenderung terjadi karena faktor internal diri sendiri maupun keluarga. Banyak juga 
hasil penelitian tentang kecemasan pada saat hamil trimester III dengan hasil yang berbeda-beda. Hal tersebut dimungkinkan terjadi perbedaan subyek penelitian, diantaranya komunitas dengan masyarakat ekonomi rendah dan pendidikan rendah maka kecemasan yang muncul dikarenakan pengetahuan yang kurang dan biaya persalinan. Beda halnya dengan penelitian kecemasan ibu hamil yang dilakukan pada komunitas masyarakat dengan pengalaman pelayanan persalinan yang kurang baik. Masa pandemic covid-19 sudah berjalan cukup lama yaitu sekitar 10 bulan. Sehingga masyarakat sudah tidak begitu memperdulikan atau sudah tidak membuat resah lagi masalah pandemi covid-19, masyarakat sudah terbiasa dengan melakukan new normal di era pandemic covid-19, sehingga masalah pandemic covid19 sudah dianggap hal yang tidak mencemaskan, ada kemungkinan jika penelitian ini dilakukan pada saat awal dimana informasi penyebaran penyakit corona sangat cepat dan mencekam.

\section{KESIMPULAN}

Kesimpulan dari penelitian ini adalah sebagai berikut :

1. Secara keseluruhan ibu hamil trimester III di era pandemic covid-19 42,9 persen tidak mengalami kecemasan, sedangkan responden yang mengalami kecemasan hanya pada tahap cemas ringan.
2. Kecemasan yang terjadi pada ibu hamil trimester III di era pandemic covid-19 banyak dialami oleh ibu hamil primigravida, sedangkan pada ibu hamil multigravida lebih banyak tidak mengalami kecemasan

3. Terdapat perbedaan kecemasan yang dialami ibu hamil trimester III pada primigravida dengan multigravida di era pandemic covid 19.

4. Pandemi covid-19 diasumsikan tidak banyak berpengaruh terhadap terjadinya kecemasan pada ibu hamil trimester III, terbukti dengan hasil penelitian ini tidak beda dengan hasil peneltian disaat tidak terjadi pandemic covid-19.

Setelah mengetahui hasil penelitian ini diharapkan:

1. Lakukan pelayanan antenatal care dengan cara professional

2. Untuk mengurangi kecemasan pada ibu hamil, lakukan pemahaman pemahaman tentang kehamilan dan persalinan, bahwa proses hamil dan melahirkan merupakan hal yang biasa bagi ibu yang berkeluarga.

3. Beri penjelasan pada ibu hamil untuk melakukan kegiatan seperti biasanya di era pandemic covid-19

4. Beri penyuluhan untuk selalu menggunakan protocol kesehatan dalam kegiatan sehari-hari.

5. Lakukan monitoring aktif melalui kegiatan posyandu ibu hamil. 


\section{DAFTAR PUSTAKA}

1. Astuti, A. B., Santosa, S. W. \& Utami, M. S. 2005. Hubungan antara dukungan keluarga dengan penyesuaian diri perempuan pada kehamilan pertama. Jurnal Psikologi. 2: 85-95.

2. Biaggi, A., Conroy, S., Pawlby, S. \& Pari- ante, C. 2016. Identifying the wo- men at risk of antenatal anxiety and depression: a systematic review. Journal of Affect Disorder, 191:62-77

3. https://lifestyle.kompas.com/read/202 0/0 3/26/112749520/tingkatkecemasan-akibatwabah-viruscorona-meningkat

4. Janiwarty B, Pieter HZ. 2013. Pendidikan Psikologi Untuk Bidan: Suatu Teori dan Terapannya. Rapha Publishing. Yogyakarta

5. Kumala Fatma Tiara, 2015. Hubungan antara kejadian Preeklampsia dan resiko depresi Antenatal. Di RSI Sunan Kudus. Tesis Universitas Sebelas Maret Surakarta

6. Kusumawati F, Hartono Y. 2012. Buku Ajar Keperawatan Jiwa. Salemba Medika. Jakarta.

7. Maimunah S. 2009. Kecemasan Ibu Hamil Menjelang Persalinan Pertama. Jurnal Humanity. 5 (1): 61-67.

8. Manuaba, Ida BagusGde, 2010. Buku IImu Kebidanan Penyakit Kandungan dan Keluarga Berencana Untuk Pendikan Bidan, Edisi 2. Jakarta: EGC.

9. Notoatmodjo Soekidjo.(2003). Pendidikan dan Perilaku Kesehatan.Jakarta: Rineka Cipta

10. Prawirohardjo, Sarwono,2009. IImu Kebidanan. Jakarta: Yayasan Bina Pustaka

11. Rahmi, L. 2010. Hubungan Usia, Tingkat Pendidikan, Dukungan Suami dan Dukungan Keluarga dengan Tingkat Kecemasan Menjelang Persalinan pada Ibu Primigravida
Trimester III Di Poliklinik Kebidanan RSUPDR. M. Djamil Padang Tahun 2009. Fakultas Keperawatan Universitas Andalas.

12. Rozikhan. 2007. Faktor-faktor risiko terjadinya preeklampsi berat di Rumah Sakit dr. Soewondo Kendal. Fakultas Kesehatan Masyarakat Universitas DIponegoro Semarang.

13. Sadock BJ, Sadock VA, Ruiz P. 2015. Kaplan Sadock's Synopsis of Psychiatry: Behavioral Sciences/Clinical Psychiatry. Edisi 11. Wolters Kluwer Health. New YorkUSA.

14. Schetter, C. D. \& Tanner, L. 2012. Anxiety, depression and stress in pregnancy: implication mothers, children, research, and practice. Curropin psy- chiatry, 25 (2): 141- 148

15. Shodiqoh ER, Syahrul F. 2014. Perbedaan Tingkat Kecemasan Dalam Menghadapi Persalinan Antara Primigravida dan Multigravida. Jurnal Berkala Epidemiologi. 2 (1): 141-150.

16. Sijangga, WN. 2010. Hubungan Antara Strategi Coping dengan kecemasan Menghadapi Persalinan pada Ibu Hamil Hipertensi. Skripsi Universitas Muhammadiyah Surakarta

17. Varney, H. 2006. buku ajar asuhan kebidanan, Jakarta, EGC. WHO. Millenium Development Goals.2012 [Accessed 06 Desember 2015].

18. Varney, H., Kriebs, J. M. \&Gegor, C. L. 2010. Varney's midwifery. Fourth edition. Jakarta: EGC.

19. Videbeck, SL. 2012. Buku Ajar Keperawatan Jiwa. EGC. Jakarta.

20. Wanda, A., Bidjuni, H. \&Kallo, V. 2014. Hubungan karakteristik ibu hamil trimester III dengan tingkat kecemasan dalam menghadapi persalinan di Poli KIA Puskesmas Tuminting. Fakultas Kedokteran Universitas Sam Ratulangi Manado. 